\title{
Evaluation of Atomic, Physical and Thermal Properties of Tellurium Powder: Impact of Biofield Energy Treatment
}

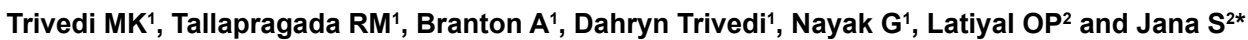 \\ ${ }^{1}$ Trivedi Global Inc., 10624 S Eastern Avenue Suite A-969, Henderson, NV 89052, USA \\ ${ }^{2}$ Trivedi Science Research Laboratory Pvt. Ltd., Hall-A, Hoshangabad Rd, Bhopal, Madhya Pradesh, India
}

\begin{abstract}
Tellurium has gained significant attention due to its photoconductivity, piezoelectricity, and thermo conductivity properties. The aim of this study was to evaluate the effect of biofield energy treatment on thermal, physical and atomic properties of tellurium powder. The tellurium powder was equally divided in two parts: control and treated $(T)$. The treated part was subjected to Mr. Trivedi's biofield energy treatment, whereas the control part was remained untreated. Subsequently, the control and treated samples were characterized using differential scanning calorimetry (DSC), thermogravimetric analysis (TGA), X-ray diffraction (XRD), and Fourier transform infrared (FT-IR) spectroscopy. The DSC data showed that latent heat of fusion was decreased by $14.13,21.90$, and $5.55 \%$ in treated samples $\mathrm{T} 1$, T2, and T3, respectively as compared to the control. However, the melting temperature did not show any change in treated samples as compared to the control. The TGA data showed that the peak width (difference in onset and endset) was increased from $213.67^{\circ} \mathrm{C}$ (control) to $234.82^{\circ} \mathrm{C}$ in treated tellurium sample. Besides, XRD results exhibited an alteration in lattice parameter, unit cell volume, density, atomic weight and nuclear charge volume of the treated tellurium powder as compared to the control. In addition, the crystallite sizes were significantly changed on crystalline plane (102) and $(110)$ as $146.05 \rightarrow 48.67 \mathrm{~nm}$ and $63.01 \rightarrow 88.21 \mathrm{~nm}$, respectively in the treated tellurium. The FT-IR spectra did not show any significant change in absorption frequencies in treated sample as compared to the control. Therefore, DSC, TGA and XRD data suggested that Mr. Trivedi's biofield energy treatment has significantly altered the thermal and physical properties of tellurium powder. Thus, biofield energy treatment could be applied to modulate the thermal and physical properties in semiconductor and chalcogenide glass industries.
\end{abstract}

Keywords: Biofield energy treatment; Tellurium; X-ray diffraction; Differential scanning calorimetry; Thermogravimetric analysis; Fourier transform infrared spectroscopy

\section{Introduction}

Tellurium (Te), chemically related to selenium and sulfur, is a rare, brittle and silver white metalloid. Tellurium and its related materials have attracted significant attention due to its photoconductivity, piezoelectricity, thermo conductivity and catalytic activities in organic reactions [1-3]. Commercially, it is used in several alloys such as steel and copper to enhance the machinability property. The considerable fraction of tellurium is used in cadmium telluride ( $\mathrm{CdTe}$ ) solar panels and as a semiconductor in various electronics industries [4]. For semiconductor applications, the orientations and size of crystallites play the vital role [5]. Furthermore, tellurium is widely used in the infrared detectors, optical modulators, fluorescent, gas sensor and chalcogenide glasses [6]. In these applications, its thermal properties such as melting point, latent heat of fusion, and thermal conductivities are the important parameters, which control the overall efficiency of the product [7]. Currently, the thermal properties are modulated by using different pressure based techniques, which are studied by various researchers $[8,9]$. Thus, after considering the importance of crystal structure parameters and thermal properties in industrial application, it is important to use an approach which can modify physical and thermal properties of tellurium.

The generation of bioelectricity in heart and brain functions due to the motion of charged particles such as protons, electrons, and ions in the human body is well known $[10,11]$. Recently, it is reported that the various scientific instruments such as Kirlian photography, polycontrast interference photography (PIP) and resonance field imaging (RFI) can measure the biofield of human body [12]. Furthermore, a human has the ability to harness the energy from environment/Universe and can transmit it to any object (living or non-living) around the Globe. The object(s) always receive the energy and respond in a useful way that is called biofield energy, and this process is known as biofield energy treatment. Moreover, the National center for complementary and alternative medicine (NCCAM) has recommended the uses of alternative CAM therapies (energy-healing) in the healthcare sector [13]. Furthermore, Mr. Trivedi's unique biofield treatment (The Trivedi Effect $)$ is known to alter the atomic, physical, structural and thermal characteristics of various metals [14-16] and ceramics [17-19]. Biofield treatment has significantly altered the latent heat of fusion in cadmium powder [20]. Recently, our group reported that biofield treatment has reduced the crystallite size by $28.6 \%$ in magnesium powder [21] and altered the bond length of $\mathrm{Ti}-\mathrm{O}$ in $\mathrm{BaTiO}_{3}$ [22]. The present work was undertaken to evaluate the impact of Mr. Trivedi's biofield energy treatment on thermal and physical properties of tellurium powder, using differential scanning calorimetry (DSC), thermogravimetric analysis (TGA), X-ray diffraction (XRD), and Fourier transform infrared (FT-IR) spectroscopy.

${ }^{*}$ Corresponding author: Dr. Snehasis Jana, Trivedi Science Research Laboratory Pvt. Ltd., Hall-A, Chinar Mega Mall, Chinar Fortune City, Hoshangabad Rd., Bhopal 462026, Madhya Pradesh, India, Tel: +91-755-6660006; E-mail: publication@trivedisrl.com

Received September 08, 2015; Accepted October 17, 2015; Published October 30, 2015

Citation: Trivedi MK, Tallapragada RM, Branton A, Trivedi D, Nayak G, et al (2015) Evaluation of Atomic, Physical and Thermal Properties of Tellurium Powder: Impact of Biofield Energy Treatment. J Electr Electron Syst 4: 162 doi:10.4172/2332-0796.1000162

Copyright: (c) 2015 Trivedi MK, et al. This is an open-access article distributed under the terms of the Creative Commons Attribution License, which permits unrestricted use, distribution, and reproduction in any medium, provided the original author and source are credited. 
Citation: Trivedi MK, Tallapragada RM, Branton A, Trivedi D, Nayak G, et al. (2015) Evaluation of Atomic, Physical and Thermal Properties of Tellurium Powder: Impact of Biofield Energy Treatment. J Electr Electron Syst 4: 162. doi:10.4172/2332-0796.1000162

Page 2 of 5

\section{Materials and Methods}

Tellurium powder was procured from Alfa Aesar, India. The sample was divided into two parts referred as control and treated. The control part remained as untreated. The treated part subjected to Mr. Trivedi for biofield energy treatment.

\section{Biofield energy treatment}

The treated samples were handed over to Mr. Trivedi for biofield energy treatment under standard laboratory conditions. Mr. Trivedi provided the biofield treatment through his energy transmission process, which includes bioenergy emission treated sample without touching. After treatment, sample was handed over in the same condition and stored at standard conditions as per the standard experimental protocol. An optimum precautionary measure was taken while evaluating the antibiogram analysis throughout the experiments. The differences in parameters before and after the treatment were noted and compared [23]. Subsequently, the control and treated samples were characterized using DSC, TGA, XRD, and FT-IR.

\section{Thermal analysis}

The thermal analysis of tellurium powder was performed using DSC and TGA-DTG techniques. For DSC study, Pyris-6 Perkin Elmer, with a heating rate of $10^{\circ} \mathrm{C} / \mathrm{min}$ under air atmosphere was used. The melting point and latent heat of fusion $(\Delta \mathrm{H})$ of control and treated tellurium sample were recorded from respective DSC thermogram. The percent change in melting point was computed using following equation:

$$
\% \text { change in melting po int }=\frac{\left[T_{\text {treated }}-T_{\text {control }}\right]}{T_{\text {control }}} * 100
$$

Where, $\mathrm{T}_{\text {Control }}$ and $\mathrm{T}_{\text {Treated }}$ are the melting point of control and treated samples, respectively. Similarly, the percent change in $\Delta \mathrm{H}$ was calculated.

Furthermore, TGA analysis was carried out using Mettler Toledo TGA-DTG system. The samples were heated from room temperature to $900^{\circ} \mathrm{C}$ with a heating rate of $10^{\circ} \mathrm{C} / \mathrm{min}$ under air atmosphere.

\section{$\mathrm{X}$-ray diffraction (XRD) study}

XRD analysis of control and treated tellurium sample was performed on Phillips, Holland PW 1710 X-ray diffractometer system. XRD system contains copper anode with a nickel filter. The radiation wavelength $1.54056 \AA$ was used by the system. The data obtained from the XRD was analyzed using PowderX software, to compute the lattice parameter, unit cell volume, density and atomic weight. The percent change lattice parameter (a) was calculated using following equation:

The crystallite size $(\mathrm{G})$ was calculated by using Scherer's equation:

$$
\mathrm{G}=\mathrm{k} \lambda /(\mathrm{b} \operatorname{Cos} \theta)
$$

Here, $\mathrm{k}$ is equipment constant $(=0.94), \lambda$ is wavelength of radiation used $(=1.54056 \AA)$, $b$ is full width half maximum (FWHM), $\theta$ is Bragg's angle. Percentage change in crystallite size was calculated using following formula:

$$
\text { Percent change in crystallite } \operatorname{size}(G)=\frac{\left[G_{\text {treated }}-G_{\text {control }}\right]}{G_{\text {control }}} * 100
$$

Here, $G_{\text {control }}$ and $G_{\text {Treated }}$ are the crystallite size of control and treated powder samples respectively. Similarly, the percent change in lattice parameter, unit cell volume, density, atomic weight, and nuclear charge per unit volume were calculated.

\section{FT-IR spectroscopy}

FT-IR spectra were recorded on Shimadzu's Fourier transform infrared spectrometer (Japan) with frequency range of 4000-500 $\mathrm{cm}^{-1}$. The analysis was accomplished to evaluate the effect of biofield treatment on dipole moment, force constant and bond strength.

\section{Results and Discussion}

\section{Thermal analysis}

To study the impact of biofield treatment on thermal properties, the tellurium powder was characterized using DSC and TGA. The DSC thermograms of control and treated tellurium samples are shown in Figures 1a-1d. The control tellurium sample showed the presence of

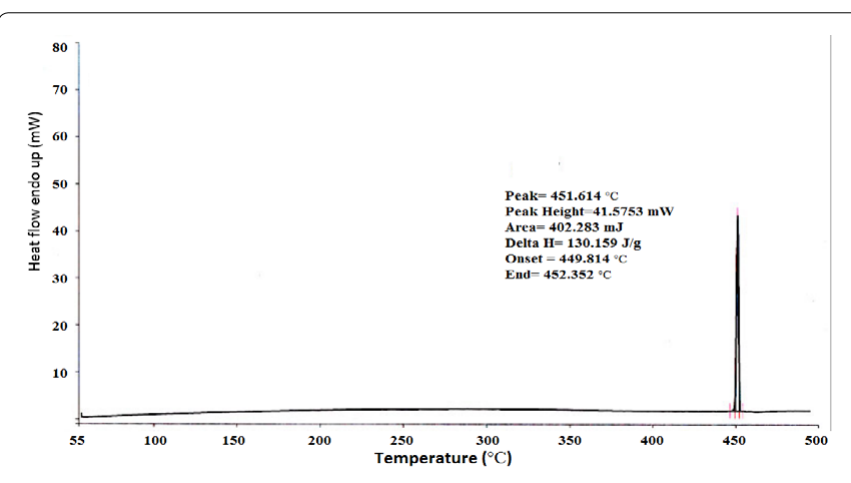

Figure 1a: DSC curve of control tellurium sample.
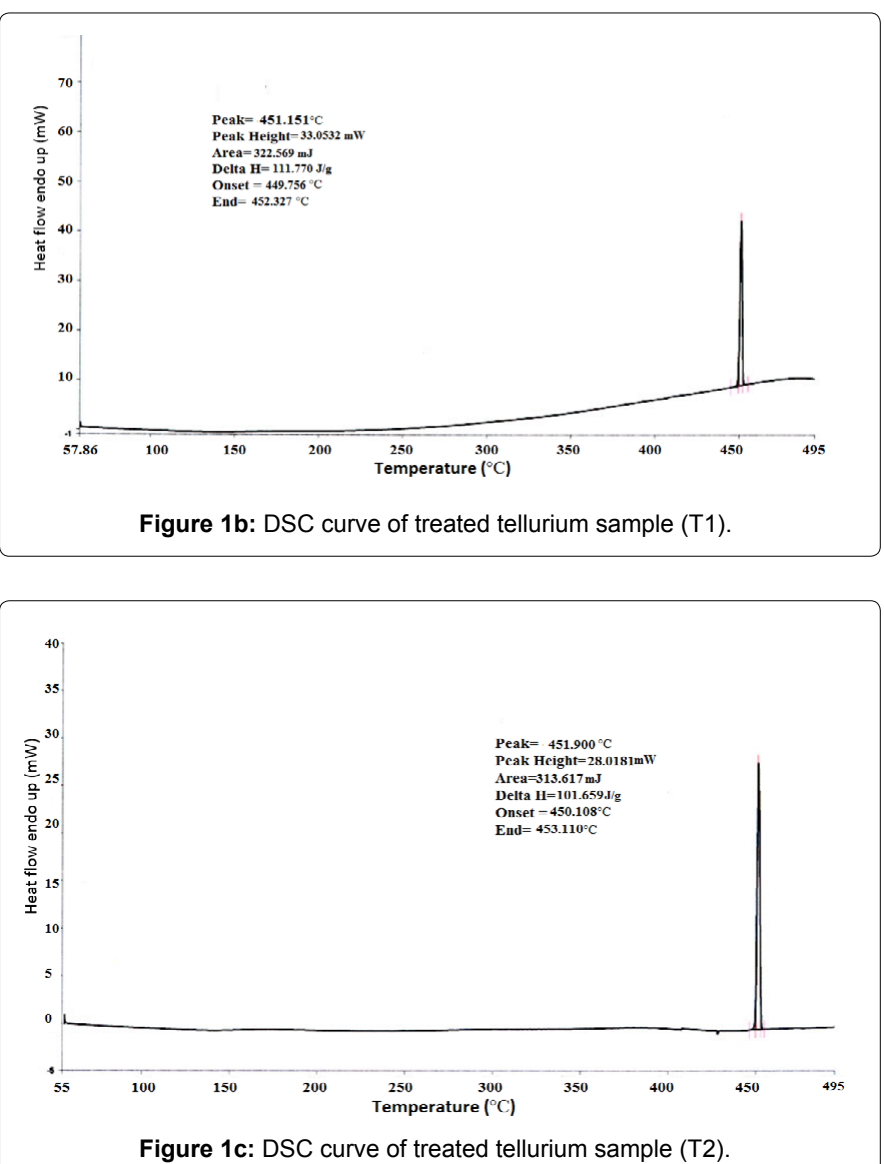


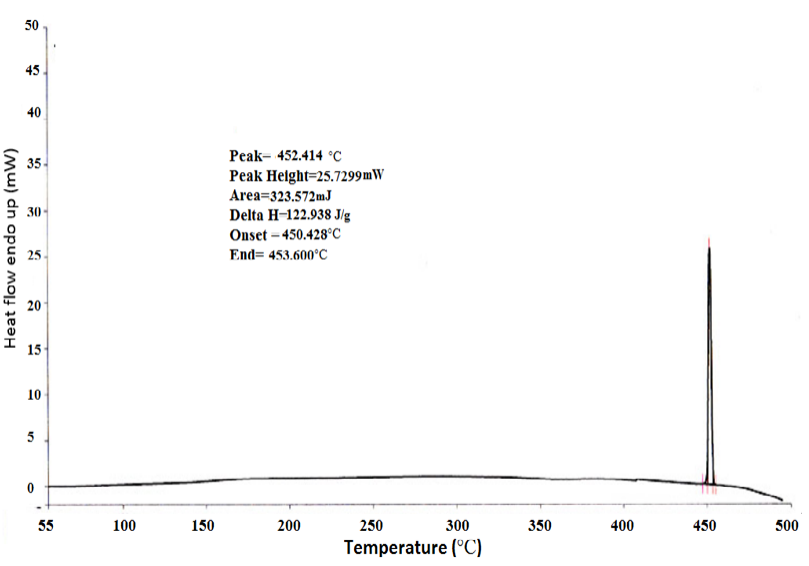

Figure 1d: DSC curve of treated tellurium sample (T3).

\begin{tabular}{|l|c|c|c|c|}
\hline Parameter & Control & T1 & T2 & T3 \\
\hline Melting Temperature $\left({ }^{\circ} \mathrm{C}\right)$ & 451.61 & 451.45 & 451.90 & 452.41 \\
\hline Latent heat of fusion, $\Delta \mathrm{H}(\mathrm{J} / \mathrm{g})$ & 130.16 & 111.77 & 101.66 & 122.94 \\
\hline Percent change in $\Delta \mathrm{H}$ & - & -14.13 & -21.90 & -5.55 \\
\hline
\end{tabular}

Table 1: Differential scanning calorimetry (DSC) analysis of tellurium powder samples.

a sharp endothermic peak at $451.61^{\circ} \mathrm{C}$ that was due to the melting temperature of the sample. The melting temperature was supported by literature data [24]. However, the melting temperature peak was observed at $451.15^{\circ} \mathrm{C}, 451.90^{\circ} \mathrm{C}$, and $452.41^{\circ} \mathrm{C}$ in treated samples $\mathrm{T} 1, \mathrm{~T} 2$, and $\mathrm{T} 3$, respectively as compared to the control. It suggests that melting point was almost similar in control and treated samples. Besides, the latent heat of fusion $(\Delta \mathrm{H})$ was observed as $130.16 \mathrm{~J} / \mathrm{g}$ in control sample, which was reduced to $111.77 \mathrm{~J} / \mathrm{g}, 101.66 \mathrm{~J} / \mathrm{g}$, and 122.94 $\mathrm{J} / \mathrm{g}$ in $\mathrm{T} 1, \mathrm{~T} 2$, and $\mathrm{T} 3$ respectively (Table 1 ). These data indicated that $\Delta \mathrm{H}$ of treated tellurium was significantly decreased by $14.13,21.90$, and $5.55 \%$ in $\mathrm{T} 1, \mathrm{~T} 2$, and $\mathrm{T} 3$ respectively as compared to the control. The latent heat of fusion is the energy required by the material to overcome the interatomic interaction force to change the phase from solid to liquid. It is reported that increase in interatomic distance reduces the interatomic attractive force [25]. Moreover, it is wellknown that the latent heat of fusion of solids decreases with decrease in interatomic attraction forces $[26,27]$. This implies that the solids with less interatomic attraction consume less thermal energy to change the phase from solids to liquid. In relation to this, it is speculated that the decrease in $\Delta \mathrm{H}$ of treated tellurium sample could be due to the decrease in interatomic attraction force after the biofield treatment. Besides, the TGA-DTG analysis results of the control and treated tellurium samples are presented in Table 2. The control sample showed the onset temperature at $391.33^{\circ} \mathrm{C}$ and endset at $605^{\circ} \mathrm{C}$. However, the onset and endset temperature were found at 453.96 and $688.78^{\circ} \mathrm{C}$, respectively in treated sample. It suggested that the peak width (difference in onset and endset) was increased from $213.67^{\circ} \mathrm{C}$ (control) to $234.82^{\circ} \mathrm{C}$ in treated samples. The peak was observed at 511.88 and $652.78^{\circ} \mathrm{C}$ in control and treated samples, respectively. In addition, the TGA results also showed the percent change in weight at peak was 21.35 and $-83.76 \%$ in control and treated samples respectively. Moreover, the ratio of percent change in weight to the peak width was 0.10 and $-0.36 \%$ in control and treated samples respectively. Thus, overall data indicated that biofield treatment has altered the thermal properties of tellurium powder. Further, in order to find the probable cause for the alteration in thermal properties, the control and treated tellurium powders were examined by X-ray diffraction.

\section{XRD study}

$\mathrm{XRD}$ is a non-destructive and quantitative technique, which has been extensively used to determine several crystal structure parameters such as crystallite size, lattice parameter etc. The XRD diffractograms of control and treated tellurium samples are presented in Figure 2. The control sample showed the crystalline peaks at Bragg's angle $(2 \theta)$ equal to $23.05^{\circ}, 27.55^{\circ}, 38.33^{\circ}, 40.45^{\circ}, 43.32^{\circ}, 45.88^{\circ}, 47.04^{\circ}, 49.69^{\circ}, 56.87^{\circ}$, $63.75^{\circ}$, and $65.9^{\circ}$, which can be attributed to crystalline plane (100), (101), (102), (110), (111), (003), (200), (201), (202), (113), and (210) respectively [28]. Further, the treated sample showed intense peaks at $2 \theta$ equal to $23.02^{\circ}, 27.57^{\circ}, 38.27^{\circ}, 40.43^{\circ}, 43.36^{\circ}, 45.92^{\circ}, 47.01^{\circ}$, $49.65^{\circ}, 56.88^{\circ}, 63.74^{\circ}$, and $65.96^{\circ}$ (Table 3 ). The data exhibited that $2 \theta$ values of treated tellurium sample were almost similar to the control. Furthermore, the crystallite sizes corresponding to all crystalline planes were calculated using Scherrer equation and presented in Table 1. The crystallite sizes corresponding to crystalline plane (100), (101), (003), and (113) were $60.33,71.01,49.94$, and $54.18 \mathrm{~nm}$, respectively in both control and treated samples. However, the crystallite sizes of treated tellurium sample were significantly altered on the crystalline plane (102), (110), (111), (200), (201), (202), and (210) as $146.05 \rightarrow 48.67 \mathrm{~nm}$, $63.01 \rightarrow 88.21 \mathrm{~nm}, 40.48 \rightarrow 26.20 \mathrm{~nm}, 90.29 \rightarrow 225.69 \mathrm{~nm}, 41.47 \rightarrow 50.68$

\begin{tabular}{|l|c|c|}
\hline Parameter & Control & Treated T1 \\
\hline Onset temperature $\left({ }^{\circ} \mathrm{C}\right)$ & 391.33 & 453.96 \\
\hline Peak temperature $\left({ }^{\circ} \mathrm{C}\right)$ & 511.88 & 652.78 \\
\hline Endset temperature $\left({ }^{\circ} \mathrm{C}\right)$ & 605.00 & 688.78 \\
\hline Peak width $\left({ }^{\circ} \mathrm{C}\right)$ & 213.67 & 234.82 \\
\hline
\end{tabular}

Table 2: TGA-DTA analysis of tellurium powder.
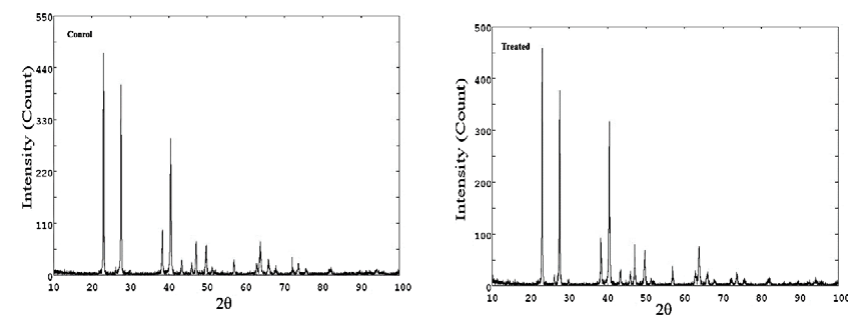

Figure 2: XRD diffractogram of tellurium powder

\begin{tabular}{|c|c|c|c|c|c|c|}
\hline & \multicolumn{3}{|c|}{ Control } & \multicolumn{3}{c|}{ Treated } \\
\hline $\begin{array}{c}\text { Crystalline } \\
\text { plane }\end{array}$ & $\begin{array}{c}\mathbf{2} \boldsymbol{\theta} \\
\text { (degree) }\end{array}$ & $\begin{array}{c}\text { FWHM } \\
\text { (degree) }\end{array}$ & $\begin{array}{c}\text { Crystallite } \\
\text { size (nm) }\end{array}$ & $\begin{array}{c}\mathbf{2} \boldsymbol{\theta} \\
\text { (degree) }\end{array}$ & $\begin{array}{c}\text { FWHM } \\
\text { (degree) }\end{array}$ & $\begin{array}{c}\text { Crystallite } \\
\text { size (nm) }\end{array}$ \\
\hline 100 & 23.05 & 0.16 & 60.33 & 23.02 & 0.16 & 60.33 \\
\hline 101 & 27.55 & 0.14 & 71.01 & 27.57 & 0.14 & 71.01 \\
\hline 102 & 38.33 & 0.08 & 146.05 & 38.27 & 0.20 & 48.67 \\
\hline 110 & 40.45 & 0.16 & 63.01 & 40.43 & 0.12 & 88.21 \\
\hline 111 & 43.32 & 0.24 & 40.48 & 43.36 & 0.36 & 26.20 \\
\hline 003 & 45.88 & 0.20 & 49.94 & 45.92 & 0.20 & 49.94 \\
\hline 200 & 47.04 & 0.12 & 90.29 & 47.01 & 0.06 & 225.69 \\
\hline 201 & 49.69 & 0.24 & 41.47 & 49.65 & 0.20 & 50.68 \\
\hline 202 & 56.87 & 0.20 & 52.31 & 56.88 & 0.12 & 94.17 \\
\hline 113 & 63.75 & 0.20 & 54.18 & 63.74 & 0.20 & 54.18 \\
\hline
\end{tabular}

Table 3: Effect of biofield treatment on Bragg's angle and crystallite size of tellurium powder. 
Citation: Trivedi MK, Tallapragada RM, Branton A, Trivedi D, Nayak G, et al. (2015) Evaluation of Atomic, Physical and Thermal Properties of Tellurium Powder: Impact of Biofield Energy Treatment. J Electr Electron Syst 4: 162. doi:10.4172/2332-0796.1000162

Page 4 of 5

\begin{tabular}{|c|c|c|c|c|c|}
\hline Group & Lattice parameter $(\AA)$ & $\begin{array}{l}\text { Unit cell volume } \\
\left.\qquad \times 10^{-23} \mathrm{~cm}^{3}\right)\end{array}$ & $\begin{array}{l}\text { Density } \\
\text { (g/cc) }\end{array}$ & $\begin{array}{c}\text { Atomic weight } \\
(\mathrm{g} / \mathrm{mol})\end{array}$ & $\begin{array}{l}\text { Nuclear charge per unit } \\
\text { volume }\left(\mathrm{C} / \mathrm{m}^{3}\right)\end{array}$ \\
\hline Control & 4.456 & 10.1695 & 6.32363 & 129.10937 & 179517 \\
\hline Treated & 4.460 & 10.1861 & 6.31333 & 129.32012 & 179082 \\
\hline Percent change & 0.08 & 0.16 & -0.16 & 0.15 & -0.24 \\
\hline
\end{tabular}

Table 4: Effect of biofield treatment on lattice parameter, unit cell volume density atomic weight, nuclear charge per unit volume of tellurium powder.

$\mathrm{nm}, 52.31 \rightarrow 94.17 \mathrm{~nm}$, and $54.84 \rightarrow 44.88 \mathrm{~nm}$, respectively after biofield treatment. This indicated that crystallite sizes were increased on plane (110), (200), (201), and (202). However, the crystallite sizes were reduced along plane (102), (111), and (210). It was reported that the structure disorder and temperature affects the crystallite sizes of the compound [29]. Thus, it is possible that biofield energy can alter the arrangement of atoms in treated tellurium powder, which may lead to alter the crystallite size. Additionally, the XRD data of control and treated samples were analyzed using PowderX software to compute the lattice parameter and volume of unit cell. The results of XRD analysis are illustrated in Table 4 . The data showed that the lattice parameter and unit cell volume of treated tellurium powder were slightly increased by 0.08 and $0.16 \%$, respectively, as compared to the control. The increase in unit cell volume led to reduce the density and nuclear charge per unit volume by 0.16 and $0.24 \%$, respectively in treated sample as compared to the control. Contrarily, the atomic weight of treated sample was slightly increased by $0.15 \%$ as compared to the control. Moreover, the increase in lattice parameter and unit cell volume suggests that tensile stress may have been applied on the unit cell of tellurium. It is assumed that the energy transferred through the biofield treatment might induce the tensile stress on the tellurium atoms, which causes them to move a little further apart. Due to this, the interatomic attraction in tellurium powder may decrease after biofield treatment. Additionally, this assumption was also supported by the decrease in latent heat of fusion in treated tellurium after biofield treatment. Therefore, XRD and DSC data revealed that biofield energy treatment has an impact on the thermal physical, and atomic properties of tellurium powder. Based on the alteration in thermal and physical properties, it is speculated that biofield energy treated tellurium powder could be more useful in semiconductor and chalcogenide glass industries.

\section{FT-IR Spectroscopy}

The FT-IR spectra of control and treated tellurium samples are presented in Figure 3. In control spectra, the absorption peak was observed at 3730 and $3124 \mathrm{~cm}^{-1}$ which can be attributed to $-\mathrm{OH}$ stretching vibrations. However, treated sample showed these peaks at 3637 , and $3145 \mathrm{~cm}^{-1}$ Moreover, the absorption peaks were observed at 2360 and $2362 \mathrm{~cm}^{-1}$ in control and treated sample respectively, which could be due to $\mathrm{CO}_{2}$ absorption by the samples. Furthermore, the absorption peaks observed was at 667 and $665 \mathrm{~cm}^{-1}$ in control and treated sample, which could be attributed to stretching vibrations of Te-O bond [30]. Thus, the FT-IR data did not show any significant change in absorption wavenumbers of treated tellurium as compared to the control.

\section{Conclusion}

Altogether, the biofield energy treatment has altered the atomic, thermal and physical properties of the tellurium powder. The latent heat of fusion was significantly reduced up to $21.90 \%$ in the treated sample as compared to the control. It could be due to decrease in interatomic attraction of the treated tellurium powder after biofield energy treatment. TGA showed that the peak width was increased

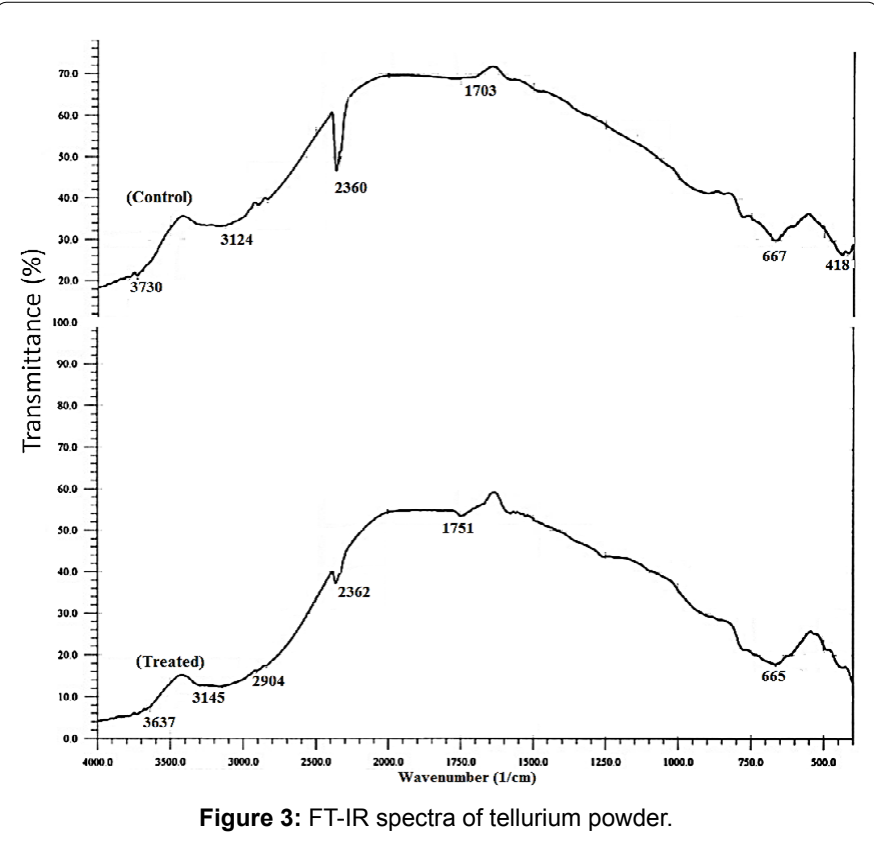

from $213.67^{\circ} \mathrm{C}$ (control) to $234.82^{\circ} \mathrm{C}$ in treated tellurium sample. The XRD data revealed that the crystallite size was significantly reduced on crystalline plane, (102) from 146.05 (control) to $48.67 \mathrm{~nm}$ in the treated tellurium sample. However the crystallite size was increased on plane, (110) from 63.01 (control) to $88.21 \mathrm{~nm}$ in the treated tellurium sample. In addition, biofield energy treatment also altered the lattice parameter, unit cell volume, density, atomic weight and nuclear charge volume of treated tellurium powder as compared to the control. Thus, the biofield treated tellurium could be more useful in semiconductor and chalcogenide glass industries.

\section{Acknowledgement}

Authors thank Dr. Cheng Dong of NLSC, Institute of Physics, and Chinese academy of sciences for permitting us to use Powder-X software for analyzing XRD results. The authors would also like to thanks Trivedi Science, Trivedi Master Wellness and Trivedi Testimonials for their support during the work.

\section{References}

1. Tangney $P$, Fahy $S$ (2002) Density-functional theory approach to ultrafast laser excitation of semiconductors: Application to the $A_{1}$ phonon in tellurium. Phys Rev B 65: 054302-054314.

2. Shih I, Champness $\mathrm{CH}$ (1978) Czochralski growth of tellurium single crystals, $J$ Cryst Growth 44: 492-498.

3. Beauvais J, Lessard RA, Galarneau P, Knystautas EJ (1990) Self-developing holographic recording in Li-implanted Te thin films, Appl Phys Lett 57: 1354 1356.

4. Zweibel K (2010) The impact of tellurium supply on cadmium telluride photovoltaics, Science 328: 699-701.

5. Suhail MH, Kaleel SG, Fahad MR (2012) Structural and electrical properties of tellurium thin films prepared by vacuum thermal deposition, Iraqi J Phys 10 : 7-11. 
Citation: Trivedi MK, Tallapragada RM, Branton A, Trivedi D, Nayak G, et al. (2015) Evaluation of Atomic, Physical and Thermal Properties of Tellurium Powder: Impact of Biofield Energy Treatment. J Electr Electron Syst 4: 162. doi:10.4172/2332-0796.1000162

Page 5 of 5

6. Sun $Z$, Zheng $Y$ (2011) Preparation of high pure tellurium from raw tellurium containing $\mathrm{Cu}$ and Se by chemical method, T Nonferrous Met Soc China 21: 665-672.

7. Jha A, Richards BDO, Jose G, Fernandez TT, Hill CJ, et al. (2012) Review on structural, thermal, optical and spectroscopic properties of tellurium oxide based glasses for fibre optic and waveguide applications, Int Mater Rev 57 357-382.

8. Deaton BC, Blum FA Jr (1965) Properties of group VI B elements under pressure. I, Melting curves of S, Se, and Te. Phys Rev 137: A1131-A1138.

9. Klement Jr W, Cohen LH, Kennedy GC (1966) Melting and freezing of selenium and tellurium at high pressures, J Phys Chem Solids 27: 171-177.

10. Movaffaghi Z, Farsi M (2009) Biofield therapies: Biophysical basis and biological regulations? Complement Ther Clin Pract 15: 35-37.

11. Neuman MR (2000) Biopotential electrodes. The biomedical engg handbook: ( $2^{\text {nd }}$ eds.), Boca Raton: CRC Press LLC

12. Prakash S, Chowdhury AR, Gupta A (2015) Monitoring the human health by measuring the biofield "aura": An overview, IJAER 10: 27637-27641.

13. Barnes PM, Powell-Griner E, Mc Fann K, Nahin RL (2004) Complementary and alternative medicine use among adults: United States, 2002. Adv Data 343: 1-19

14. Trivedi MK, Tallapragada RM (2008) A transcendental to changing meta powder characteristics. Met Powder Rep 63: 22-28, 31.

15. Trivedi MK, Patil S, Tallapragada RMR (2015) Effect of biofield treatment on the physical and thermal characteristics of aluminium powders, Ind Eng Manag 4: 151.

16. Dhabade VV, Tallapragada RM, Trivedi MK (2009) Effect of external energy on atomic, crystalline and powder characteristics of antimony and bismuth powders, Bull Mater Sci 32: 471-479.

17. Trivedi MK, Tallapragada RM (2009) Effect of super consciousness external energy on atomic, crystalline and powder characteristics of carbon allotrope powders. Mater Res Innov 13: 473-480.

18. Trivedi MK, Patil S, Tallapragada RM (2013) Effect of biofield treatment on the physical and thermal characteristics of vanadium pentoxide powder. J Material Sci Eng S11: 001

19. Trivedi MK, Tallapragada RM, Branton A, Trivedi D, Nayak G, et al. (2015) Characterization of Physical, Thermal and Structural Properties of Chromium (VI) Oxide Powder: Impact of Biofield Treatment. J Powder Metall Min 4.

20. Trivedi MK, Nayak G, Patil S, Tallapragada RM, Latiyal O, et al. (2015) An evaluation of biofield treatment on thermal, physical and structural properties of cadmium powder. J Thermodyn Catal 6: 147.

21. Trivedi MK, Tallapragada RM, Branton A, Trivedi D, Nayak G, et al. (2015) Potential impact of biofield treatment on atomic and physical characteristics of magnesium, Vitam Miner 3: 129.

22. Trivedi MK, Nayak G, Patil S, Tallapragada RM, Latiyal O, et al. (2015) Impact of biofield treatment on atomic and structural characteristics of barium titanate powder, Ind Eng Manage 4: 166.

23. Trivedi MK, Nayak G, Patil S, Tallapragada RM, Latiyal O (2015) Studies of the atomic and crystalline characteristics of ceramic oxide nano powders after bio field treatment, Ind Eng Manage 4: 161.

24. Kracek FC (1941) The melting point of tellurium, J Am Chem Soc 63: 1989-1990.

25. Padmavathi DA (2011) Potential energy curves and material properties, Mater Sci Appl 2: 97-104

26. Sharma HP, Srivastava Y (2010) National defence academy examination Upkar Prakashan. India.

27. Middleton B, Phillips J, Thomas R, Stacey S (2012) Physics in anaesthesia Royal College of General Practitioners.

28. Mayers B, Xia Y (2002) One-dimensional nanostructures of trigonal tellurium with various morphologies can be synthesized using a solution-phase approach, J Mater Chem 12: 1875-1881.

29. Britto S, Joseph S, Kamath PV (2010) Distinguishing crystallite size effects from those of structural disorder on the powder X-ray diffraction patterns of layered materials, J Chem Sci 122: 751-756.

30. Carotenuto G, Palomba M, Nicola SD, Ambrosone G, Coscia U (2015) Structural and photoconductivity properties of tellurium/PMMA films, Nanoscale Res Lett 10: 313 